\title{
Influence of Moisture Content on Physical and Mechanical Properties of Cedrelinga catenaeformis Wood
}

\author{
Larissa Soriani Zanini Ribeiro Soares, ${ }^{\mathrm{a}}$ Iuri Fazolin Fraga, ${ }^{\mathrm{a}}$ Lucimar de Souza e Paula, \\ Felipe Nascimento Arroyo, ${ }^{a}$ Heloiza Candeia Ruthes, ${ }^{a}$ Vinícius Borges de Moura \\ Aquino, ${ }^{\mathrm{c}}$ Júlio Cesar Molina, ${ }^{\mathrm{d}}$ Tulio Hallak Panzera, ${ }^{\mathrm{e}}$ Luiz Antonio Melgaço Nunes \\ Branco, ${ }^{\mathrm{f}}$ Eduardo Chahud, ${ }^{\mathrm{f}}$ André Luis Christoforo, ${ }^{\mathrm{a}}$ and Francisco Antonio Rocco Lahr ${ }^{\mathrm{g}}$
}

This study aimed to investigate the influence of moisture content variation on 12 mechanical properties of the Cedrelinga catenaeformis species. Of the 12 properties, four were significantly affected (based on analysis of variance at $5 \%$ significance level), and the compression and shear strengths in the direction parallel to the fibers exhibited the greatest difference in values from the saturated moisture condition of up to $12 \%$ (approximately $34 \%$ increase). Toughness exhibited a behavior different from that predicted by the normative equation, in which increase in moisture content implied increase (approximately 59\%) of the property studied. Because a good part of the properties was not significantly affected and Brazilian standard ABNT NBR 7190 (1997) considers expressions that lead to a considerable increase in mechanical properties with the reduction of moisture content, this approach was unfavorable to the safety of the project, motivating the development of other studies to collaborate in revisions of this normative document.

Keywords: Cedrelinga catenaeformis; Correction of moisture content; Strength and stiffness

Contact information: a: Department of Civil Engineering (DECiv), Federal University of Sao Carlos, Sao Carlos, Brazil; b: Department of Civil Engineering, Federal Institute of Triângulo Mineiro, Uberaba, Brazil; c: Department of Civil Engineering, Federal University of the South and Southeast of Pará, Santana do Araguaia, Brazil; d: Department of Mechanical Engineering, Paulista State University, Itapeva, Brazil; e: Department of Mechanical Engineering, Federal University of São João Del-Rei, São João Del-Rei, Brazil; f: Department of Civil Engineering, Federal University of Minas Gerais, Pampulha; g: Wood and Timber Structures Laboratory, Department of Structural Engineering, Sao Carlos School of Engineering of Sao Carlos, University of Sao Paulo (USP), Sao Carlos/SP, Brazil;

*Corresponding author: lipe.arroyo@gmail.com

\section{INTRODUCTION}

Wood is a natural renewable material, available in large quantities, and a great resource for structural constructions. Among the materials commonly used in structures, wood presents a high relationship between strength-to-weight and its production generates few environmental impacts (Guzel 2020; Silva et al. 2020).

The total area of trees planted in Brazil in 2019 amounts to 9 million hectares and the country is a world reference for forestry technology. The Brazilian sector has the highest productivity in considering the volume of wood produced per area per year, and for one of the shortest cycles between planting and harvesting in the world. In 2019, Brazil had an average productivity of $35.3 \mathrm{~m}^{3} / \mathrm{ha}$ per year in Eucalyptus plantations (IBA 2020). 
Cedroarana (Cedrelinga catenaeformis) is a wood species with natural distribution in Colombia, Peru, and Brazil (Amazonas, Rondônia, Mato Grosso, and Pará). It presents an average value of compressive strength parallel to the fibers and apparent density of 46.6 $\mathrm{MPa}$ and $0.52 \mathrm{~g} / \mathrm{cm}^{3}$, respectively (ITTO 2021).

Wood can be used as a structural material and is a component of other subsystems (Araujo et al. 2016). For structural purposes, with safety and economy, it requires the knowledge of its physical and mechanical properties (Trevisan et al. 2007; Almeida et al. 2013). In this context, conducting experiments to characterize the properties of species used as a structural element is of supreme importance. Lack of knowledge of these wood species attributes makes its correct use unfeasible.

One of the factors to be evaluated during the characterization process is the percentage of moisture content present in the wood, as this variable has a great influence on its physical and mechanical properties. In general, the strength and stiffness properties of wood increase with the decrease in moisture content (Kretschmann 2008), which is explained by the increase in density and stiffness of cell walls, as well as the percentage of woody material, caused by water loss and wood contraction (Echenique and Robles 1993).

The corrective models for wood strength and stiffness properties for equilibrium moisture present using the Brazilian standard ABNT NBR 7190 (1997) consider an increase in the linear variation of such properties with a decrease in moisture content. However, as wood is a natural, heterogeneous, and anisotropic material, certain properties may not be affected by large differences in moisture content.

In this context, several studies using various methodologies have been carried out with the purpose of evaluating and quantifying the cited influence (Carll and Wiedenhoeft 2009; Silva et al. 2012; Báder and Németh 2019; Korkmaz and Büyüksari 2019).

In Brazil, the design of structures and test methods for wood characterization are carried out in accordance with the guidelines established by the Brazilian regulatory standard (NBR) of the Brazilian Association of Technical Standards (ABNT), ABNT NBR 7190 (1997). The aforementioned normative document adopts a reference moisture for characterizing the strength and stiffness properties of a given batch of material, and the various moisture contents must be corrected to the standard of $12 \%$. In addition, it indicates that wood in structural application with moisture content above $20 \%$ should not be used, as the wood strength and stiffness undergo variations during the hygroscopic interval until reaching the fibers' saturation point (FSP, moisture content close to 30\%) from which it is considered that the modulus of elasticity remains constant (Segundinho et al. 2017).

Since the Brazilian standard for wooden structures requires laboratory tests to be carried out with a humidity of $12 \%$, this study used analysis of variance (ANOVA) at the $5 \%$ significance level to investigate the influence of moisture content variation (from fiber saturation point to $12 \%$ equilibrium moisture content) on 12 mechanical properties of Cedrelinga catenaeformis wood to confirm the adequacy of the standard ABNT NBR7190 (1997), which corrects for $12 \%$ of the moisture content the values of the physicalmechanical properties obtained in the experimental tests. 


\section{EXPERIMENTAL}

\section{Materials}

The experiments were performed at the laboratory of wood and wood structures (LaMEM), Department of Structural Engineering, School of Engineering of São Carlos (EESC), University of São Paulo (USP), which has the necessary equipment for characterizing the physical-mechanical properties of wood samples.

The wooden pieces, with nominal dimensions of $6 \mathrm{~cm} \times 16 \mathrm{~cm} \times 330 \mathrm{~cm}$, of Cedroarana (Cedrelinga catenaeformis), from the south of the state of Roraima (Brazil), were supplied in green condition and also air-dried by a company in the sector, located in the region of the city of São Carlos (Brazil, SP). It should be noted that the homogeneous lot had approximately $1 \mathrm{~m}^{3}$.

The physical and mechanical properties (Table 1) were determined following the methods of the Brazilian standard ABNT NBR 7190 (1997). It should be noted that 12 specimens were made to perform each type of test and for each moisture content level (12\% and fiber saturation point), which resulted in 372 experiments in total.

Table 1. Physical and Mechanical Properties Evaluated

\begin{tabular}{|c|c|}
\hline Abbreviation & Properties \\
\hline$\rho_{12}\left(\mathrm{~g} / \mathrm{cm}^{3}\right)$ & Apparent Density \\
\hline$\rho_{\mathrm{FSP}}\left(\mathrm{g} / \mathrm{cm}^{3}\right)$ & Fiber Saturation Point Density \\
\hline$\varepsilon_{\mathrm{rt}}(\%)$ & Radial Shrinkage \\
\hline$\varepsilon_{\mathrm{tt}}(\%)$ & Tangential Shrinkage \\
\hline$f_{\mathrm{c} 0}(\mathrm{MPa})$ & Compressive Strength Parallel to the Fibers \\
\hline$f_{\mathrm{t} 0}(\mathrm{MPa})$ & Tensile Strength Parallel to the Fibers \\
\hline$f_{\mathrm{t} 90}(\mathrm{MPa})$ & Tensile Strength Perpendicular to the Fibers \\
\hline$f_{\mathrm{v} 0}(\mathrm{MPa})$ & Shear Strength in the Direction Parallel to the Fibers \\
\hline$f_{\mathrm{s} 0}(\mathrm{MPa})$ & Cracking Resistance Parallel to the Fibers \\
\hline$f_{\mathrm{tm}}(\mathrm{MPa})$ & Conventional Strength in Static Bending Test \\
\hline$E_{\mathrm{co}}(\mathrm{MPa})$ & Elastic Modulus in Compression Parallel to the Fibers \\
\hline$E_{\mathrm{t} 0}(\mathrm{MPa})$ & Modulus of Elasticity in Traction Parallel to the Fibers \\
\hline$E_{\mathrm{tm}}(\mathrm{MPa})$ & Conventional Modulus of Elasticity in the Static Bending Test \\
\hline$f_{\mathrm{h} 0}(\mathrm{MPa})$ & Hardness Parallel to the Fibers \\
\hline$f_{\mathrm{h} 90}(\mathrm{MPa})$ & Hardness Perpendicular to the Fibers \\
\hline$W(\mathrm{daN} \cdot \mathrm{m})$ & Toughness \\
\hline
\end{tabular}

With the moisture content of the samples close to $12 \%$, the strength and modulus of elasticity values were corrected for the moisture content of $12 \%\left(f_{12}\right.$ and $\left.E_{12}\right)$ using Eqs. 1 and 2 (ABNT NBR 7190 1997), respectively, in which $f_{U}$ and EU consist of the samples' strength and stiffness associated with the $U$ moisture content. It should be noted that the use of such expressions is recommended for moisture content values between $12 \%$ and $20 \%$ :

$$
\begin{aligned}
& f_{12}=f_{U} \cdot\left[1+\frac{3 \cdot(U-12)}{100}\right] \\
& E_{12}=E_{U} \cdot\left[1+\frac{2 \cdot(U-12)}{100}\right]
\end{aligned}
$$


Knowing the values of strength and stiffness properties in the moisture content associated with the fibers' saturation point and also close to equilibrium moisture $(\approx 12 \%)$, Eqs. 1 and 2 were also used in an attempt to estimate the properties for $12 \%$ moisture starting from the moisture content of the experimentally determined fiber saturation point.

Based on the corrected values (close to $12 \%$ to exactly $12 \%$ ) of the compressive strength in the direction parallel to the fibers $\left(f_{\mathrm{c} 0,12}\right)$, Eq. 3 was used to determine the characteristic value $\left(f_{\mathrm{c} 0, \mathrm{k}}\right)$ for the categorization of wood into one of the strength classes of the hardwood group (C20, C30, C40, and C60), where $f_{1}, f_{2}$ to $f_{\mathrm{n}}$ denote the compressive strength values $\left(f_{\mathrm{c} 0,12}\right)$ in ascending order of the ' $n$ ' test specimens used (here $\left.n=12\right)$ :

$$
f_{c 0, k}=\operatorname{Max}\left\{\begin{array}{c}
f_{1} \\
0.7 \cdot \frac{\sum_{i=1}^{n} f_{i}}{n} \\
1.1 \cdot\left[2 \cdot\left(\frac{f_{1}+f_{2}+f_{3}+\ldots+f_{(n / 2)-1}}{(n / 2)-1}\right)-f_{n / 2}\right]
\end{array}\right.
$$

\section{Analysis}

Analysis of variance (ANOVA), at a 5\% significance level, using the Minitab ${ }^{\circledR} 19$ Statistical Software (Minitab, LLC, State College, PA, USA) was used to confirm the influence of moisture content variation (from $12 \%$ to moisture associated with the fiber saturation point) on the examined properties. From ANOVA, a p-value (probability p) below the significance level implies a significant difference in the means of a given property caused by the variation in moisture content, and non-significance otherwise.

Both Anderson-Darling and Multiple Comparisons tests also evaluated at 5\% significance level, were used to verify normality in the distribution of residuals and equality of variances. A p-value equal to or greater than the significance level implies meeting both requirements, which validates the ANOVA model.

\section{RESULTS AND DISCUSSION}

Table 2 shows the results of the evaluated properties of Cedroarana wood related to the moisture content of $12 \%$ (corrected values) and also the FSP. It is noteworthy that the average values of moisture contents obtained at the fiber saturation point as well as those close to equilibrium moisture (12\% - ABNT NBR 7190) were equal to $27.11 \%$ and $12.53 \%$, respectively. Table 2 also presents the values of the ratios between the properties obtained for the moisture content corrected to $12 \%$ and the fiber saturation point (12\%/FSP), as well as the ANOVA results (5\% significance). Anderson-Darling and Multiple Comparison test p-values ranged from 0.096 to 0.456 and 0.116 to 0.720 , which validates the results of the ANOVA. The NBR 7190 (ABNT, 1997) limits the $C V$ to $18 \%$ and $28 \%$ for the properties in the normal and tangential directions, respectively. Table 2 shows that the $C V s$ obtained are within the limit imported by the standard.

Of the 12 mechanical properties evaluated, 9 properties resulted in lower coefficients of variation (CV) when obtained for a moisture content equal to the fiber's saturation point. Studies carried out by Bodig and Jayne (1992), Logsdon and Calil (2002), and Claisse (2016) found that the strength of wood decreases with increasing moisture content, up to the fiber saturation point, after which there is no further reduction and the value remains constant, a fact that justifies the reduction of the coefficients of variation from the fiber saturation point. 
Table 2. Results of Physical and Mechanical Properties of Cedroarana Wood

\begin{tabular}{|c|c|c|c|c|c|c|}
\hline \multirow{2}{*}{ Properties } & \multicolumn{2}{|c|}{ MC $\mathbf{1 2 \%}$} & \multicolumn{2}{c|}{ MC - FSP } & \multirow{2}{*}{ p-value } & \multirow{2}{*}{ 12\%/FSP } \\
\cline { 2 - 5 } & $\overline{\boldsymbol{x}}$ & $\mathbf{C V}(\%)$ & $\overline{\boldsymbol{x}}$ & $\mathbf{C V}(\%)$ & & 0.90 \\
\hline$\rho\left(\mathrm{g} / \mathrm{cm}^{3}\right)$ & 0.57 & 11.61 & 0.63 & 11.13 & 0.046 & --- \\
\hline$\varepsilon_{\mathrm{rt}}(\%)$ & 3.54 & 23.17 & --- & --- & --- & --- \\
\hline$\varepsilon_{\mathrm{tt}}(\%)$ & 6.55 & 19.01 & --- & --- & --- & 1.34 \\
\hline$f_{\mathrm{c} 0}(\mathrm{MPa})$ & 42.23 & 25.32 & 31.49 & 18.26 & 0.006 & 1.13 \\
\hline$f_{\mathrm{t} 0}(\mathrm{MPa})$ & 62.73 & 28.34 & 55.60 & 27.82 & 0.305 & 1.04 \\
\hline$f_{\mathrm{t} 90}(\mathrm{MPa})$ & 3.03 & 19.26 & 2.92 & 22.78 & 0.687 & 1.35 \\
\hline$f_{\mathrm{t} 0}(\mathrm{MPa})$ & 12.18 & 28.86 & 9.05 & 28.30 & 0.021 & 0.99 \\
\hline$f_{\mathrm{s} 0}(\mathrm{MPa})$ & 0.58 & 27.42 & 0.58 & 12.54 & 0.901 & 1.09 \\
\hline$f_{\mathrm{tm}}(\mathrm{MPa})$ & 61.13 & 14.97 & 56.02 & 14.80 & 0.166 & 1.16 \\
\hline$E_{\mathrm{co} 0}(\mathrm{MPa})$ & 10522 & 12.91 & 9100 & 12.23 & 0.010 & 1.09 \\
\hline$E_{\mathrm{t} 0}(\mathrm{MPa})$ & 11118 & 16.22 & 10233 & 15.61 & 0.216 & 1.02 \\
\hline$E_{\mathrm{tm}}(\mathrm{MPa})$ & 10228 & 9.48 & 10047 & 16.67 & 0.748 & 1.12 \\
\hline$f_{\mathrm{h} 0}(\mathrm{MPa})$ & 57.81 & 28.54 & 51.54 & 25.25 & 0.313 & 1.17 \\
\hline$f_{\mathrm{h} 90}(\mathrm{MPa})$ & 36.54 & 23.24 & 31.12 & 26.89 & 0.129 & 0.63 \\
\hline$W(\mathrm{daN} \cdot \mathrm{m})$ & 0.51 & 28.33 & 0.81 & 23.93 & 0.000 & 0.63 \\
\hline
\end{tabular}

From ANOVA, evaluated at the $5 \%$ level of significance, $p$-value less than 0.05 implies the nonequivalence of the property means, and equivalence otherwise

The characteristic value of the compressive strength in the direction parallel to the fibers, obtained through Eq. 3, was 29.56 MPa. Thus, Cedroarana wood belongs to the C20 strength class $\left(20 \mathrm{MPa} \leq f_{\mathrm{c} 0, \mathrm{k}}<30 \mathrm{MPa}\right)$, as found by Aquino et al. (2018).

According to the ANOVA results of the six resistance properties investigated, only two $\left(f_{\mathrm{c} 0}, f_{\mathrm{v} 0}\right)$ were significantly affected by the variation in moisture content. The compressive strength value in the direction parallel to the wood fibers at $12 \%$ moisture was $34 \%$ higher than the value of this property in the saturated condition. A similar result was obtained in relation to the shear strength in the direction parallel to the fibers. The values of the other strength properties $\left(f_{\mathrm{t} 0}, f_{\mathrm{t} 90}, f_{\mathrm{s} 0}\right.$, and $\left.f_{\mathrm{tm}}\right)$ were not affected by the variation in moisture content; that is, the strength values for these four properties can be considered constant or independent of the associated moisture content, which differs from the linear variation model adopted by Eq. 1.

Of the three evaluated stiffness properties, only the compression elastic modulus in the direction parallel to the fibers $\left(E_{\mathrm{c} 0}\right)$ of the wood was significantly affected. The average value of $E_{\mathrm{c} 0}$ for the $12 \%$ moisture condition was $16 \%$ higher than the value of this property for the wood in the saturated condition with a moisture content of $27.11 \%$. The modulus of elasticity to tension in the direction parallel to the fibers $\left(E_{\mathrm{t} 0}\right)$ and to bending $\left(E_{\mathrm{tm}}\right)$ were not affected by the variation in moisture content, which is different from the proposed model of Eq. 2, in which the modulus of elasticity increases linearly with the decrease in moisture content.

Regarding toughness $(W)$, this property was significantly affected by the variation in moisture content, in which an increase in moisture of $12 \%$ for the fiber saturation point resulted in an increase of 59\%. This effect was contrary to that established in the Eqs. 1 and 2 considered in the estimation of strength and stiffness, in which the progressive increase in moisture content impacts the reduction of these properties. At this point, it is worth noting that the density was also significantly affected by the moisture content, in which the $12 \%$ increase in the fiber saturation point resulted in a $10.53 \%$ increase in this property. Christoforo et al. (2020) showed, through the study of regression models involving species with varied densities, a good correlation between apparent density and 
calculated toughness at $12 \%$ moisture. The authors found that increases in density values impacted increases in toughness values. The same effect was also found in this study.

Table 3 shows the results of the estimated mean values (Est.) of the strength and stiffness properties using Eqs. 1 and 2, as well as the associated errors (Er.).

Table 3. Results of the Estimation of the Mean Values of Strength and Stiffness

\begin{tabular}{|c|c|c|c|c|}
\hline Properties & Exper. & Est. & Diff. = Exper. - Est. & Er. (\%) \\
\hline$f_{\mathrm{co}}(\mathrm{MPa})$ & 42.23 & 45.82 & -3.59 & 8.51 \\
\hline$f_{\mathrm{t} 0}(\mathrm{MPa})$ & 62.73 & 80.65 & -17.92 & 28.56 \\
\hline$f_{\mathrm{t} 90}(\mathrm{MPa})$ & 3.03 & 4.27 & -1.24 & 40.93 \\
\hline$f_{\mathrm{v} 0}(\mathrm{MPa})$ & 12.18 & 13.20 & -1.02 & 8.36 \\
\hline$f_{\mathrm{s} 0}(\mathrm{MPa})$ & 0.58 & 0.85 & -0.27 & 46.03 \\
\hline$f_{\mathrm{tm}}(\mathrm{MPa})$ & 61.13 & 81.67 & -20.54 & 33.60 \\
\hline$E_{\mathrm{c} 0}(\mathrm{MPa})$ & 10522 & 11849 & -1327 & 12.61 \\
\hline$E_{\mathrm{t} 0}(\mathrm{MPa})$ & 11118 & 13288 & -2170 & 19.52 \\
\hline$E_{\mathrm{t}}(\mathrm{MPa})$ & 10228 & 13086 & -2858 & 27.94 \\
\hline
\end{tabular}

From the ANOVA in Table 2, it was found that only $f_{\mathrm{c} 0}, f_{\mathrm{v} 0}$, and $E_{\mathrm{c} 0}$ were significantly affected by the variation in moisture content. From Table 3, it can be seen that the lowest error values came from the estimates associated with these three properties. Because the order of error was close for both strength and stiffness, by the models, it appears that the variation in moisture content affects strength and stiffness in the same proportion, a result that is different from the experimental result, as the strength increases (34\% and 35\%) and stiffness (16\%) with the reduction in moisture content were different. Such results point to greater strength gain than stiffness gain.

Because the other properties of strength and stiffness $\left(f_{\mathrm{t} 0}, f_{\mathrm{t} 90}, f_{\mathrm{s} 0}, f_{\mathrm{tm}}, E_{\mathrm{t} 0}\right.$, and $\left.E_{\mathrm{tm}}\right)$ were not significantly affected by the variation in moisture content, the error in the estimates of these properties was higher than the errors found for $f_{\mathrm{c} 0}, f_{\mathrm{v} 0}$, and $E_{\mathrm{c} 0}$, and this indicates that the equations must be adjusted by type of mechanical request. It is worth noting that the estimates were higher than the average values of the properties determined experimentally, which results are unfavorable to the safety of the structures.

If the expressions of the Brazilian standard ABNT NBR 7190 (1997) are used for moisture content values close to $20 \%$, it should be noted that these expressions are considered for moisture contents ranging between $10 \%$ and $20 \%$, but estimated values are still expected, significantly higher than experimental values, and this calls attention to a need for development of new research on the subject.

\section{ACKNOWLEDGEMENTS}

This research was financed in part by the Coordenação de Aperfeiçoamento de Pessoal de Nível Superior - Brazil (CAPES) - Finance Code 001.

\section{CONCLUSIONS}

1. Only three of the nine properties of strength and stiffness tests were significantly affected by the variation in moisture content, implying little precision by the equations for estimating the strength and stiffness of wood proposed by the Brazilian standard ABNT NBR 7190 (1997), which predict a linear increase in strength and stiffness properties with a reduction in moisture content. 
2. All estimated strength and stiffness properties presented values higher than those determined experimentally, which reinforces the need for systemic revision of these equations, usually considered in projects.

3. Reducing the moisture content of the fiber saturation point $(27.11 \%)$ to $12 \%$ promoted significant increases only in the values of compressive strength in the direction parallel to the fibers (34\%), in shear strength parallel to the fibers $(35 \%)$, and in the modulus of elasticity to compression in the direction parallel to the fibers (16\%). Because of the additions in such properties, a greater gain in strength values was noticed.

4. The toughness of the wood significantly increased (59\%) with the $12 \%$ moisture content increase for the fiber saturation point, as did the density, which also increased $(10.53 \%)$ with the increase in the moisture content.

5. It is notable that 8 of the 12 properties of strength and stiffness, about $67 \%$ were not influenced by the variation in moisture content and also that the estimated properties were all significantly higher than the values determined experimentally. Studies involving other species are essential to reach more decisive conclusions regarding the effects of variation in moisture content, as well as the accuracy of models for correcting the strength and stiffness of wood, and those results that may lead to new versions of the Brazilian standard.

\section{REFERENCES CITED}

ABNT NBR 7190 (1997). "Projeto de estruturas de madeira [Design of wooden structures]," Brazilian Association of Technical Standards, Rio de Janeiro, Brazil.

Almeida, D. H., Scaliante, R. M., Macedo, L. B., Macêdo, A. N., Dias, A. A., Christoforo, A. L., and Calil Junior, C. (2013). "Structural characterization of the amazonian wood specie Paricá (Schizolobium amazonicum Herb) in members," Revista Árvore 37(6), 1175-1181. DOI: 10.1590/s0100-67622013000600019

Araujo, V. A., Cortez-Barbosa, J., Gava, M., Garcia, J. N., Souza, A. J. D., Savi, A. F., Morales, E. A. M., Molina, J. C., Vasconcelos, J. S., and Christoforo, A. L. (2016). "Classification of wooden housing building systems," BioResources 11(3), 78897901. DOI: 10.15376/biores.11.3.DeAraujo

Aquino, V. B. M., Almeida, D. H., Almeida, T. H., Panzera, T. H., Christoforo, A. L., and Rocco Lahr, F. A. (2018). "Physical and mechanical characterization of Cedrelinga catenaeformis Ducke wood specie," International Journal of Materials Engineering 8(5), 97-100. DOI: 10.5923/j.ijme.20180805.03

Báder, M., and Németh, R. (2019). "Moisture-dependent mechanical properties of longitudinally compressed wood," European Journal of Wood and Wood Products 77(6), 1009-1019. DOI: 10.1007/s00107-019-01448-1

Bodig, J., and Jayne, B. A. (1992). Mechanics of Wood and Wood Composites, Van Nostrand Reinhold Company Inc., New York, NY, USA.

Carll, C., and Wiedenhoeft, A. (2009). "Moisture-related properties of wood and the effects of moisture on wood and wood products," in: Moisture Control in Buildings: The Key Factor in Mold Preventions, H. R. Trechsel, and M. T. Bomberg (Eds.), ASTM International, West Conshohocken, PA, USA, pp. 54-79.

Claisse, P. A. (2016). "Timber," in: Civil Engineering Materials, Elsevier, Waltham, MA, USA, pp. 369-386. DOI: 10.1016/b978-0-08-100275-9.00033-4 
Christoforo, A. L., Almeida, D. H., Varanda, L. D., Panzera, T. H., and Lahr, F. A. R. (2020). "Estimation of wood toughness of Brazilian tropical tree species," Engenharia Agricola 40, 1-6. DOI: 10.1590/1809-4430-Eng.Agric.v40n2p232237/2020

Echenique, M. R., and Robles, F. V. (1993). Ciencia y Tecnología De La Madera I. Veracruz, Universidad Veracruzana, Veracruz, México.

Guzel, T. A. (2020). "Consumer attitudes toward preference and use of wood, woodenware, and furniture: A sample from Kayseri, Turkey," BioResources 15(1), 28-37. DOI: $10.15376 /$ biores.15.1.28-37

Indústria Brasileira de Árvores (IBÁ) (2020). IBA Annual Report 2020, IBÁ, São Paulo. Brazil.

International Tropical Timber Organization (ITTO) (2021). "Cedrelinga cateniformis," (http://www.tropicaltimber.info/pt-br/specie/cedrorana-cedrelingacateniformis/\#lower-content), Acessed 25 June 2021.

Korkmaz, O., and Büyüksarı, Ü. (2019). "Effects of moisture content on mechanical properties of micro-size oak wood," BioResources 14(4), 7655-7663. DOI: 10.15376/biores.14.4.7655-7663

Kretschmann, D. E. (2008). “The influence of juvenile wood content on shear parallel, compression, and tension perpendicular to grain strength and mode I fracture toughness of loblolly pine at various ring orientation," Forest Products Journal 58(78), 89-96.

Logsdon, N. B., and Calil, C. J. (2002). "Influence of moisture on the strength and stiffness properties of wood," Cadernos de Engenharia de Estruturas 18(1), 77-107.

Segundinho, P. G. A., Carreira, M. R., Regazzi, A. J., and Dias, A. A. (2017). "Influence of moisture content on the determination of the modulus of elasticity of Pinus sp. beams," Ambiente Construído 17(3), 319-329. DOI: 10.1590/s167886212017000300179

Silva, D. A. L., Lahr, F. A. R., Faria, O. B., and Chahud, E. (2012). "Influence of wood moisture content on the modulus of elasticity in compression parallel to the grain," Materials Research 15(2), 300-304. DOI: 10.1590/s151614392012005000025

Silva, L. S. Z. R. S., Fernandes, F. P. D., Paula, L. S., and Lahr, F. A. R. (2020). "Evaluation of the variability of compressive strength parallel to the fibers of hardwood species," Maderas. Ciencia y Tecnología 22(2), 205-212. DOI: 10.4067/s0718-221x2020005000207

Trevisan, H., Tieppo, F. M. M., Carvalho, A. G., and Lelis, R. C. C. (2007). "Evaluation of physical and mechanical properties of wood from five species as a function of deterioration in two environments," Revista Árvore 31(1), 93-101. DOI: $10.1590 / \mathrm{s} 0100-67622007000100011$

Article submitted: July 2, 2021; Peer review completed: August 10, 2021; Revised version received and accepted: August 11, 2021; Published: August 13, 2021. DOI: $10.15376 /$ biores.16.4.6758-6765 